\title{
Quality assessment and anti-obesity activity of Stellaria media (Linn.) Vill
}

\author{
Neerja Rani, Neeru Vasudeva* and Surendra Kumar Sharma
}

\begin{abstract}
Background: Obesity is recognized as a social problem, associated with serious health risks and increased mortality. Numerous trials have been conducted to find and develop new anti-obesity drugs through herbal sources to minimize side effects associated with the present anti-obesity drugs. The present study was designed to evaluate the quality control parameters, quantitative phytochemical analysis (total phenolic, total flavonoids and total saponin content), and the anti-obesity effect of lyophilized juice (LJ) of Stellaria media (Linn.) Vill. by employing in vitro and in vivo models.
\end{abstract}

Methods: In vitro studies were performed to evaluate the inhibitory activity of $L J$ on pancreatic amylase and lipase. The in vivo pancreatic lipase activity was evaluated by measurement of plasma triacylglycerol levels after oral administration of lipid emulsion to swiss albino mice. Furthermore, the anti-obesity effect of $L J$ was assessed at two doses, $400 \mathrm{mg} / \mathrm{kg}$ and $900 \mathrm{mg} / \mathrm{kg}$ body weight in mice fed a high-fat-diet with or without $L J$ for 6 weeks.

Results: The $L J$ inhibited pancreatic amylase and lipase activity in vitro and elevated plasma triacylglycerol level in mice. $L J$ suppressed the increase in body weight, retroperitoneal adipose tissue, liver weights and serum parameters viz., total cholesterol, total triglyceride, LDL-cholesterol level at the dose of $900 \mathrm{mg} / \mathrm{kg}$ body weight of the mice fed with high fat diet. The total phenolic, flavonoid and saponin contents were found to be $0.26 \mathrm{mg} / \mathrm{g}, 1.4 \mathrm{mg} / \mathrm{g}$ and $1.19 \mathrm{\mu g} / \mathrm{g}$ respectively of $L$.

Conclusion: The anti-obesity effects of $L J$ in high-fat-diet fed mice may be partly mediated through delaying the intestinal absorption of dietary fat and carbohydrate by inhibiting digestive enzymes.

Keywords: Stellaria media, Anti-obesity activity, a-amylase, Lyophilized juice, High-fat-diet

\section{Background}

Obesity is defined as excessive accumulation of body fat that may impair health. It has become a worldwide epidemic [1]. Obesity is known to be related to increase risks of coronary heart diseases, hypertension, noninsulin-dependent diabetes mellitus and certain type of cancer [2]. The major factor contributing to obesity is imbalance between energy intake and expenditure [3]. One most important strategy in the treatment of obesity includes the development of nutrient digestion and absorption inhibitors, in an attempt to reduce the energy intake through gastrointestinal mechanisms without altering any central mechanisms. Inhibition of digestive enzymes is one of the most widely studied mechanisms

\footnotetext{
* Correspondence: neeruvasudeva@gmail.com

Department of Pharmaceutical Sciences, Guru Jambheshwar University of Science and Technology, Hisar, Haryana 125001, India
}

used to determine the potential efficacy of natural products as anti-obesity agents. The medicinal foods are known to have not only nutritive and taste values but also medicinal effects, and they are prescribed in various traditional preparations [4]. At present, the potential of natural products for the treatment of obesity is still largely unexplored and might be an excellent alternative strategy for the development of safe and effective antiobesity drugs [5]. In course of search for a plant used as enzymes inhibitor, the investigation was directed towards the anti-obesity activity of LJ of Stellaria media.

Stellaria media (Linn.) Vill. (Caryophylaceae) commonly known as Chickweed, is a favourite salad herb widely distributed throughout the Himalayas upto an altitude of $4300 \mathrm{~m}$ [6]. The species is medicinal and edible, rich in vitamins, minerals, flavonoids, triterpenoids, Gamma-linolenic-acid, phenols and beta carotene. Various 
phytoconstituents viz; lipids [7], pentasaccharide [8], and triterpenoid [9] have been reported from this species. It has been used to treat various diseases because of many biological activities in traditional medicine, such as inflammations of the digestive, renal, respiratory and reproductive tracts. It also possesses diuretic, expectorant, antiasthmatic and antifeedant properties [10]. Its water is an old wives' remedy for obesity [11]. However, the effect of this plant on the obesity has not yet been examined. Therefore, present work was undertaken to study the antiobesity potential of LJ of Stellaria media employing various in vitro and in vivo assay systems.

\section{Methods}

Chemicals

Pancreatic $\alpha$ amylase, pancreatic lipase and glycyrrhizic acid were purchased from Sigma (Aldrich Co. St. Louis, MO, USA). Methanol (HPLC grade), casein, soluble starch, vitamin and mineral mixture, glyceryl trioleate, lecithin, sodium cholate and TES buffer were purchased from Hi-media. All other chemicals were of reagent grade.

\section{Animals}

Male swiss albino mice (5 weeks old) were used for the in vivo models. The animals were housed for 1 week under a $12 \mathrm{~h} / 12 \mathrm{~h}$ light/dark cycle in a temperature humidity-controlled room. The animals were given free access to food and water. After adaptation to the lighting conditions for 1 week, the healthy animals were used in the in vivo models. The experimental protocols were approved by the Institutional Animal Ethical Committee, Guru Jambheshwar University of Science and Technology, Hisar (Regn No 0436).

\section{Plant material}

The fresh plant of Stellaria media (Linn.) Vill. was collected from the campus of Guru Jambheshwar University of Science and Technology, Hisar. The plant was taxonomically identified and authenticated by Dr. H.B. Singh, Head, Raw Materials Herbarium and Museum Division of National Institute of Science Communication and Information Resources. The voucher specimen has been deposited in the herbarium section of the Pharmacognosy Division, Department of Pharmaceutical Sciences, Guru Jambheshwar University of Science and Technology, Hisar for further reference.

\section{Preparation of lyophilized juice}

$500 \mathrm{~g}$ of fresh herb was taken into blender cup of a mixer and blended for $10 \mathrm{~min}$ to make fine slurry. The final slurry was filtered through muslin cloth. The filtrate was frozen and lyophilized (Alpha 2-4 LD Plus) at
$5 \mu \mathrm{m} \mathrm{Hg}$ pressure at $-50^{\circ} \mathrm{C}$. The $\mathrm{LJ}$ was placed in a plastic bottle, and then stored at $-20^{\circ} \mathrm{C}$ until used.

\section{Quality control parameters of $\mathrm{L}$}

The LJ was subjected to various quality control parameters according to Indian Pharmacopoeia [12] and WHO Guidelines [13]. The physico-chemical parameters viz; ash values, loss on drying, heamolytic activity; heavy metal analysis (Lead, Cadmium, Arsenic), microbial (E. coli, Salmonella Sp., S. aureus) and aflatoxin (B1 + B2 + G1 + G2) contamination were determined. The preliminary phytochemical screening was also performed for the presence of major phytochemical constituents in LJ according to standard methods [14].

\section{Quantitative analysis of $\mathrm{LJ}$}

\section{Determination of total phenolic content}

The total phenolic content of LJ was estimated using the Folin-Ciocalteu method adapted from Singleton and Rossi [15]. LJ (0.02 ml, $1 \mathrm{mg} / \mathrm{ml})$ was oxidized with $0.25 \mathrm{ml}$ of $10 \%(\mathrm{v} / \mathrm{v})$ Folin-Ciocalteu's reagent and neutralized by adding $1.25 \mathrm{ml}$ of $20 \%$ sodium carbonate. The absorbance was measured at $685 \mathrm{~nm}$ after incubating at $40^{\circ} \mathrm{C}$ for $40 \mathrm{~min}$. Results are expressed as $\mathrm{mg} / \mathrm{g}$ of gallic acid.

\section{Determination of total flavonoid content}

The $\mathrm{AlCI}_{3}$ method adapted from Lamaison and Carnet [16] was used for the determination of the total flavonoid content of the LJ. $0.4 \mathrm{ml}(10 \mathrm{mg} / \mathrm{ml})$ of LJ was added to $2 \mathrm{ml}$ of a solution of $2 \% \mathrm{AlCI}_{3} 6 \mathrm{H}_{2} \mathrm{O}$. After proper mixing, the mixture was incubated for $10 \mathrm{~min}$ at ambient temperature. The absorbance of the solution was read at $440 \mathrm{~nm}$. Flavonoid contents are expressed in $\mathrm{mg} / \mathrm{g}$ of quercetin.

\section{Determination of total saponin content}

For total saponin content determination $2 \mathrm{~g}$ of LJ was blended with $2 \mathrm{ml}$ of concentrated $\mathrm{NH}_{4} \mathrm{OH}$ (37\%) for $3 \mathrm{~min}$. The $\mathrm{pH}$ of solution was adjusted to a $\mathrm{pH} 7.0$ with $\mathrm{H}_{3} \mathrm{PO}_{4}$ and then $1 \mathrm{ml}$ of $10 \%$ diastase was added. This was incubated at $37^{\circ} \mathrm{C}$ for $30 \mathrm{~min}$, cooled to room temperature, and transferred to a $100 \mathrm{ml}$ volumetric flask with $\mathrm{CH}_{3} \mathrm{OH}$. The final extract was diluted to volume with additional $\mathrm{CH}_{3} \mathrm{OH}$ and filtered through Whatman No. 42 paper prior to analyses [17]. Before injection to HPLC column, extracts were filtered through a $0.45 \mu \mathrm{m}$ membrane filter (Millipore, Bedford, USA).

Chromatographic analyses were carried out on the HPLC system (Agilent Technologies 1260 infinity) consisted of 1260 DVD-VL/ 1260 ALS/ 1260 Binary pump and UV/ visible detector. Separation of saponins was done using a Zorbax Eclise XDB-C18 (Analytical 4.6 $250 \mathrm{~mm} \mathrm{ID}$, particle size $5 \mu \mathrm{m}$ ) column at $1.5 \mathrm{ml} / \mathrm{min}$ 
flow rate. Detection was made at $245 \mathrm{~nm}$ at $25^{\circ} \mathrm{C}$. The analysis used $20 \mu \mathrm{l}$ of a sample solution. The mobile phase consisted of methanol, water and acetic acid in the ratio of $(60: 34: 6 \mathrm{v} / \mathrm{v})$. The solvents were filtered and degassed prior to use. The glycyrrhizic acid was used as standard. Quantification of the saponin is expressed in $\mu \mathrm{g} / \mathrm{g}$ of $\mathrm{LJ}$ and determined by a standard curve from a plot of the peak area and matching concentration of the standard solution.

\section{Measurement of a-amylase inhibitory activity}

The activity was measured using the method reported by Xiao et al. [18] and Yoshikawa et al. [19] with slight modifications. Substrate solution was prepared by dissolving soluble starch $(500 \mathrm{mg})$ in $25 \mathrm{~mL}$ of $0.4 \mathrm{M}$ $\mathrm{NaOH}$ and heating for $5 \mathrm{~min}$ at $100^{\circ} \mathrm{C}$. After cooling in ice $\mathrm{H}_{2} \mathrm{O}$, the $\mathrm{pH}$ of solution was adjusted to 7 with $2 \mathrm{M}$ $\mathrm{HCl}$, and water was added to adjust the volume to $100 \mathrm{ml}$. LJ solutions were prepared by dissolving in acetate buffer ( $\mathrm{pH}$ 6.5) to make 1, 2, 3, 4 and $5 \mathrm{mg} / \mathrm{ml}$ solutions. The substrate $(40 \mu \mathrm{L})$ and $\mathrm{LJ}(20 \mu \mathrm{L})$ solutions were mixed in a micro plate well and the mixtures were pre-incubated at $37^{\circ} \mathrm{C}$ for $3 \mathrm{~min}$. Then $20 \mu \mathrm{L}$ of $\alpha$-amylase solution $(50 \mu \mathrm{g} / \mathrm{ml})$ was added to each well, and the plate was incubated for $15 \mathrm{~min}$. The reaction was terminated by adding $80 \mu \mathrm{L}$ of $0.1 \mathrm{M} \mathrm{HCL}$; then $200 \mu \mathrm{L}$ of $1 \mathrm{mM}$ iodine solution was added. The absorbance (Abs) was measured at $650 \mathrm{~nm}$. Inhibitory activity was calculated as follows:

$$
\text { Inhibition }(\%)=\{1-(\mathrm{Abs} 2-\mathrm{Abs} 1) /(\mathrm{Abs} 4-\mathrm{Abs} 3) \mathrm{X} 100\}
$$

Where Abs 1 is the absorbance of incubated solution containing LJ, starch and amylase; Abs 2 is the absorbance of incubated solution containing LJ and starch; Abs 3 is the absorbance of incubated solution containing starch and amylase; Abs 4 is the absorbance of incubated solution containing starch.

\section{Measurement of pancreatic lipase inhibitory activity}

Lipase inhibitory activity was measured according to the method of Han et al. [20] with slight modifications. Substrate solution was prepared by sonication (10 $\mathrm{min}$ in an ice bath) of a mixture of glyceryl trioleate $(80 \mathrm{mg})$, lecithin $(10 \mathrm{mg})$, and sodium cholate $(5 \mathrm{mg})$ suspended in $9 \mathrm{ml}$ of $0.1 \mathrm{M}$ TES buffer ( $\mathrm{pH} 7.0$ ). LJ was dissolved in $0.1 \mathrm{M}$ TES buffer to make $1,2,3,4$ and $5 \mathrm{mg} / \mathrm{ml}$ solutions. The substrate $(20 \mu \mathrm{l})$ and sample solutions $(20 \mu \mathrm{l})$ in microplate wells were preincubated for $3 \mathrm{~min}$; then $10 \mu \mathrm{l}$ of lipase solution $(20 \mu \mathrm{g} / \mathrm{ml})$ was added to each reaction mixture and incubated for $30 \mathrm{~min}$ at $37^{\circ} \mathrm{C}$. The absorbance was measured at $550 \mathrm{~nm}$ using a microplate reader. Inhibitory activity (\%) was calculated as follows:

$$
\text { Inhibition }(\%)=\{1-(\text { Abs6-Abs5) } /(\text { Abs8-Abs7)X100 }\}
$$

Where Abs 5 is the absorbance of incubated solution containing LJ, substrate and lipase; Abs 6 is the absorbance of incubated solution containing LJ and substrate; Abs 7 is the absorbance of incubated solution containing substrate and lipase; Abs 8 is the absorbance of incubated solution containing substrate.

\section{Plasma triacylglycerol level after oral administration of lipid emulsion to mice}

The animals were divided in three groups and deprived of food overnight. Test groups were orally administered lipid emulsion $(5 \mathrm{ml} / \mathrm{kg})$ with LJ $(400 \mathrm{mg} / \mathrm{kg})$ and $(900 \mathrm{mg} / \mathrm{kg})$ respectively. Positive control group was given lipid emulsion alone. The oil emulsion was prepared with $7 \mathrm{ml}$ of olive oil, $93 \mathrm{mg}$ of cholic acid and $7 \mathrm{ml}$ of deionized water. Food was withdrawn during the test. Blood samples were collected from the ophthalmic venous plexus at $0,1,2,3$, 4 and $5 \mathrm{~h}$ using a heparinaized capillary tube, and centrifuged at $6300 \mathrm{rpm}$ for $10 \mathrm{~min}$. Plasma triacylglycerol levels were measured using a commercial triglyceride assay kit (Erba diagnostics).

\section{High-fat-diet induced obesity}

Male swiss albino mice (5 weeks old) were acclimatized for 1 week, fed a high-fat diet (HFD) for 2 weeks and randomly divided into four groups matched for body weight [21]. Each group contained six animals (one animal per cage). Control group was fed normal diet; (g/100 g food : corn starch, 40; sugar, 10; vitamin mixture, 1; mineral mixture, 4; casein, 20; cellulose, 5; soybean oil, 17; methionine, 3; $433.2 \mathrm{Kcal} / 100 \mathrm{~g})$. Test groups received LJ $(400 \mathrm{mg} / \mathrm{kg})$ and $(900 \mathrm{mg} / \mathrm{kg})$ along with high-fat diet for six weeks orally. Positive control group received only high-fat diet for six weeks. The composition of high-fat diet was; (g/100 g food): corn starch, 10; sugar, 10; lard, 40; vitamin mixture, 1 ; mineral mixture, 4; casein, 20; cellulose, 5; soybean oil, 7; methionine, 3. The Kcal of HFD was 583 $\mathrm{Kcal} / 100 \mathrm{~g}$. The total food intake by each group was recorded at least twice weekly, and the body weight of each mouse was recorded once weekly. At the end of the experiment, the blood was taken by venous puncture under anesthesia with diethyl ether, and the mice were then killed with an overdose of diethyl ether. Experiments were performed in a ventilated room. The serum was prepared and frozen at $-80^{\circ} \mathrm{C}$ until analysis. The liver and retroperitonal adipose tissue were dissected and weighed. The triglyceride (TG), total cholesterol (TC), HDL-cholesterol, LDLcholesterol was measured using Triglyceride E-Test and Total Cholesterol E-Test kits.

\section{Histopathological study}

For histopathological studies livers of the scarified mice were dissected, removed, washed with normal saline and put in $10 \%$ formalin solution. The fixed specimens were 


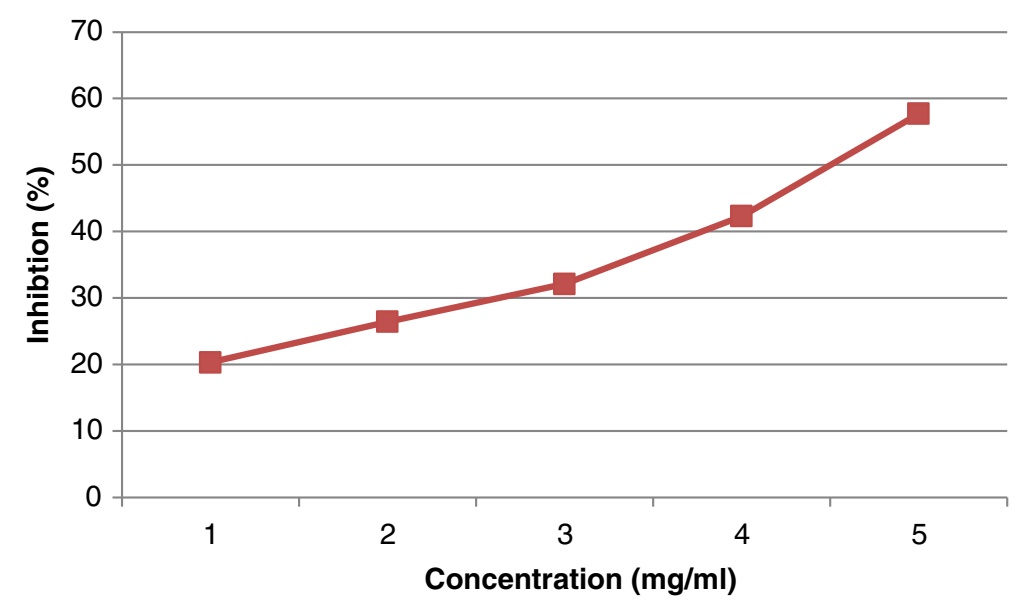

Figure 1 Inhibitory effect of $L J$ on a-amylase.

then trimmed, washed and dehydrated in ascending grades of alcohol. The tissue specimens were cleared in xylene, embedded in paraffin, sectioned at 4-6 $\mu$ thickness, stained with Haematoxylin-Eosin ( $\mathrm{H}$ and E) [22].

\section{Statistical analysis}

All the results were expressed as mean \pm standard error of mean (SEM). The data of all the groups were analyzed using one-way ANOVA followed by Dunnett's $t$-test using the software Instat 3.0. In all the tests, the criterion for statistical significance was $\mathrm{p}<0.05$.

\section{Results}

\section{Quality control parameters of $\mathrm{L}$}

The physicochemical parameters total ash, water soluble ash, and acid-insoluble ash were found to be 20.5, 12.5 and $8.65 \% \mathrm{w} / \mathrm{w}$ respectively. The percentage moisture content was found to be $9 \% \mathrm{w} / \mathrm{w}$. The haemolytic activity was found to be 0.66 units/g. The preliminary phytochemical screening of the LJ indicated the presence of mainly carbohydrates, saponins, phenols, tannins and flavonoids. The Atomic Absorption Spectroscopy study showed the presence of cadmium, lead, arsenic in LJ but below the WHO permissible limits and therefore safe to use. LJ showed complete absence of E. coli, Salmonella typhi, and Staphylococcus aureus. Aflatoxin $(\mathrm{B} 1+\mathrm{B} 2+\mathrm{G} 1+\mathrm{G} 2)$ were found to be less than $5 \mathrm{ppb}$.

\section{Total phenolic, flavonoid and saponin content}

The total phenolic content in LJ was found to be $0.26 \mathrm{mg} / \mathrm{g}$ in gallic acid equivalents. The content of flavonoids, in quercetin equivalents in $\mathrm{mg} / \mathrm{g}$ of plant

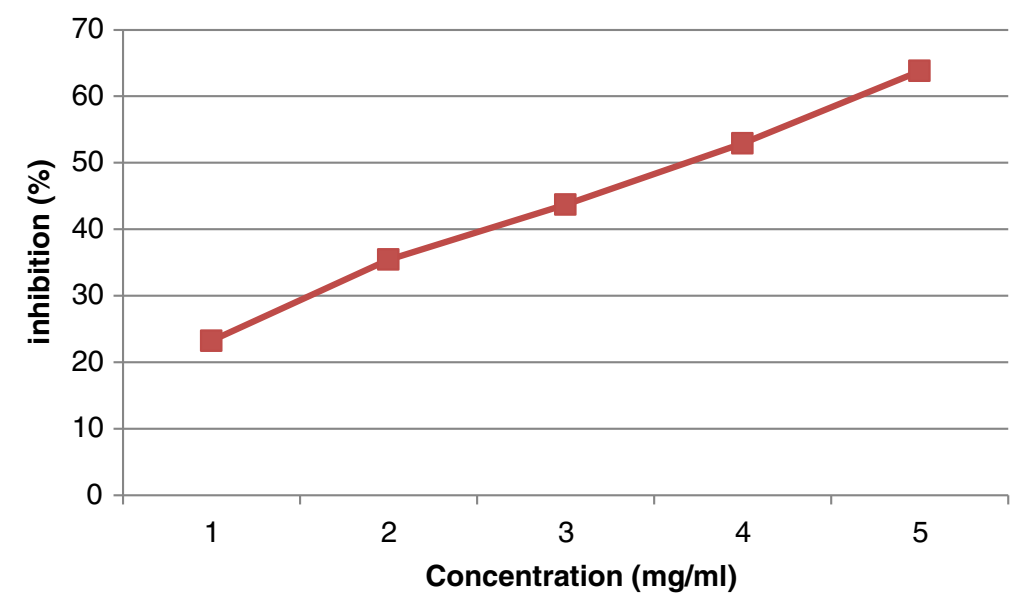

Figure 2 Inhibitory effect of LJ on Pancreatic Lipase. 


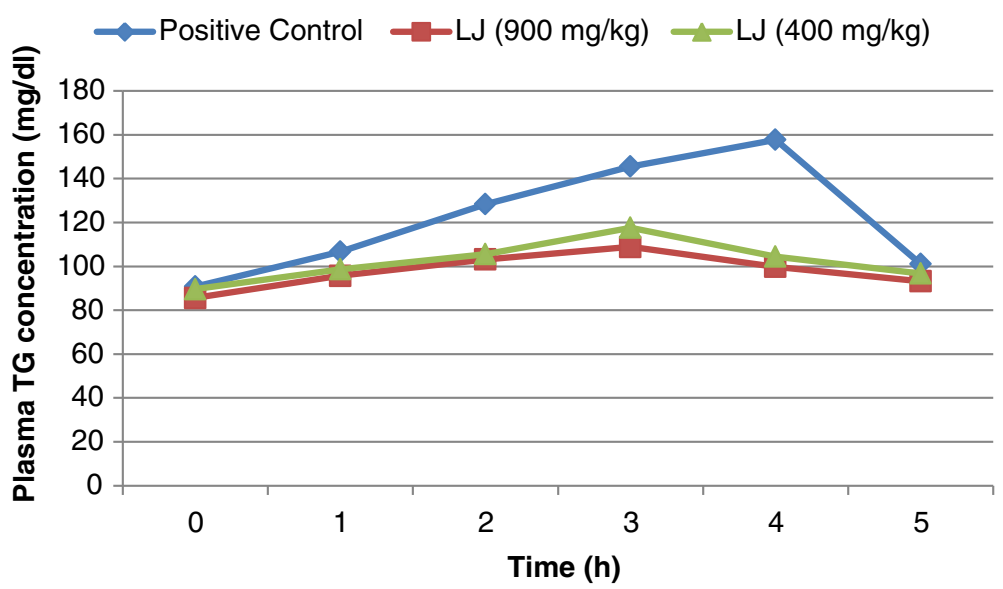

Figure 3 Effect of $L$ on elevation of the plasma triacylglycerol (TG) level after oral administration of a lipid emulsion. Values are means \pm SEM.

extract was found to be $1.4 \mathrm{mg} / \mathrm{g}$. The concentration of total saponin in LJ was found to be $1.19 \mu \mathrm{g} / \mathrm{g}$ of LJ as quantified with HPLC.

\section{Effect of $L J$ on pancreatic a-amylase and lipase activity} The inhibitory activity of LJ against pancreatic $\alpha$-amylase and lipase was determined using different concentrations $(1,2,3,4,5 \mathrm{mg} / \mathrm{ml})$ ) of LJ. As shown in Figure 1. and Figure 2. LJ inhibited the enzyme activities in a dosedependent way. The inhibition of lipase by $\mathrm{LJ}\left(\mathrm{IC}_{50}\right.$ value; $3.71 \mathrm{mg} / \mathrm{ml}$ ) was stronger than that of $\alpha$-amylase $\left(\mathrm{IC}_{50}\right.$ value; $4.53 \mathrm{mg} / \mathrm{ml}$ ).

Effect of $\mathrm{LJ}$ on the plasma triacylglycerol levels after oral administration of lipid emulsion to mice

Figure 3. shows the serial changes in plasma triacylglycerol concentration when lipid emulsion with or without LJ was administered orally to mice. At 3 and $4 \mathrm{~h}$ after administration of LJ, the plasma triacylglycerol concentrations were significantly lower in group administered $900 \mathrm{mg} / \mathrm{kg}$ of LJ than those in the positive control group. There was no significant reduction in plasma triacylglycerol levels at the dose of $400 \mathrm{mg} / \mathrm{kg}$ body weight.
Effect of $\mathrm{LJ}$ on food consumption, body, retroperitoneal adipose tissue, liver weight and serum parameters in mice fed a high-fat-diet for 6 weeks

The mean food consumption per week per mice was different between the control and high-fat-diet groups throughout the whole experimental period, but it did not differ between the groups fed high-fat-diet alone and high-fat-diet plus LJ treated group, suggesting that the anti-obesity effect of LJ was not mediated by a reduction of food intake (Table 1). The change in body weight of the groups during the experimental period of 6 weeks is shown in Table 1. The LJ at the dose of $900 \mathrm{mg} / \mathrm{kg}$ significantly suppressed the body weight gain when compared to the group fed on high-fat diet alone during experimental period. The oral administration of LJ to high-fat-diet induced obese mice for 6 weeks caused significant reductions in retropertonial adipose tissues and liver weight at the dose of $900 \mathrm{mg} / \mathrm{kg}$ body weight as compared to high-fat-diet. The LJ at the dose of $400 \mathrm{mg} / \mathrm{kg}$ body weight did not cause significant reduction in body weight, retropertonial adipose tissue, and liver weight [Table 1]. The serum concentrations of TG, cholesterol, and LDL-cholesterol were significantly lowered in the

Table 1 Effect of LJ of Stellaria media on the body weight, food intake, parametrial fat and liver weight in mice fed on the high-fat-diet for 6 weeks orally

\begin{tabular}{|c|c|c|c|c|}
\hline Group & Body weight gain (g) & Total food intake (kcal) & Retroperitoneal fat (g) & Liver weight (g) \\
\hline \multicolumn{5}{|c|}{ (Kcal) } \\
\hline Control & $2.81 \pm 0.28$ & $29.15 \pm 0.10$ & $0.98 \pm 0.11$ & $3.13 \pm 0.11$ \\
\hline HF diet & $6.21 \pm 0.75$ & $41.97 \pm 0.25$ & $2.32 \pm 0.37$ & $4.45 \pm 0.35$ \\
\hline HF diet $+\llcorner J$ & $5.36 \pm 0.75$ & $41.01 \pm 0.73$ & $1.59 \pm 0.17$ & $4.023 \pm 0.24(400 \mathrm{mg} / \mathrm{kg})$ \\
\hline HF diet + LJ & $2.41 \pm 1.35^{*}$ & $40.46 \pm 0.63$ & $0.92 \pm 0.11^{* *}$ & $3.58 \pm 0.11^{*}(900 \mathrm{mg} / \mathrm{kg})$ \\
\hline
\end{tabular}

Data are expressed as mean \pm SEM, $\mathrm{n}=6,{ }^{*} P<0.05,{ }^{*} P<0.01$ compared with high-fat-diet group. 
Table 2 Effect of LJ of Stellaria media on the blood parameters in mice

\begin{tabular}{lllll}
\hline $\begin{array}{l}\text { Serum } \\
\text { parameter }\end{array}$ & Control & HF diet & $\begin{array}{l}\text { HF diet }+ \text { LJ } \\
(\mathbf{4 0 0} \mathbf{~ m g} / \mathbf{k g})\end{array}$ & $\begin{array}{c}\text { HF diet + L } \\
\mathbf{( 9 0 0 ~} \mathbf{~ m g} / \mathbf{k g})\end{array}$ \\
\hline Total triglyceride & $88.72 \pm 3.02$ & $125.62 \pm 5.70$ & $110.50 \pm 5.31$ & $95.88 \pm 3.96^{* *}(\mathrm{mg} / \mathrm{dl})$ \\
Total cholesterol & $132.23 \pm 9.87$ & $200.90 \pm 17.34$ & $181.47 \pm 13.88$ & $141.41 \pm 12.03^{*}(\mathrm{mg} / \mathrm{dl})$ \\
HDL-cholesterol & $68.06 \pm 5.33$ & $43.88 \pm 3.41$ & $51.8 \pm 4.24$ & $59.8 \pm 3.99^{*}(\mathrm{mg} / \mathrm{dl})$ \\
LDL-cholesterol & $56.16 \pm 10.07$ & $136.09 \pm 15.97$ & $111.23 \pm 14.33$ & $69.99 \pm 9.13^{* *}(\mathrm{mg} / \mathrm{dl})$ \\
\hline
\end{tabular}

Data are expressed as mean $\pm \mathrm{SEM}, \mathrm{n}=6,{ }^{*} P<0.05,{ }^{* *} P<0.01$ compared with high-fat-diet group.

group fed high-fat-diet and treated with $\mathrm{LJ}$ at the dose of $900 \mathrm{mg} / \mathrm{kg}$ body weight, than in the control group fed on the high-fat-diet alone. The LJ at the dose of $400 \mathrm{mg} / \mathrm{kg}$ body weight did not cause significant reduction in serum parameters when compared to group receiving high-fatdiet alone [Table 2].

\section{Histopathological study}

Histopathological examination of liver of the control group mice fed on normal diet revealed normal histological picture of hepatic lobule which consists of central vein surrounded by normal hepatocytes (Figure 4a).
Examination of liver of mice fed on high-fat-diet showed fatty degeneration of hepatocytes and infiltration of leucocytes in hepatic sinusoid (Figure 4b). Liver of mice given orally LJ $(900 \mathrm{mg} / \mathrm{kg}$ ) showed marked improvement in fatty degeneration with no observed pathological lesions (Figure 4c). The LJ at the dose of $400 \mathrm{mg} / \mathrm{kg}$ body weight showed little vacuolar degeneration of hepatocytes and some improvement in fatty degeneration (Figure 4d).

\section{Discussion}

Obesity is one of the major reasons for increase in incidence of coronary heart diseases, hypertension, non-
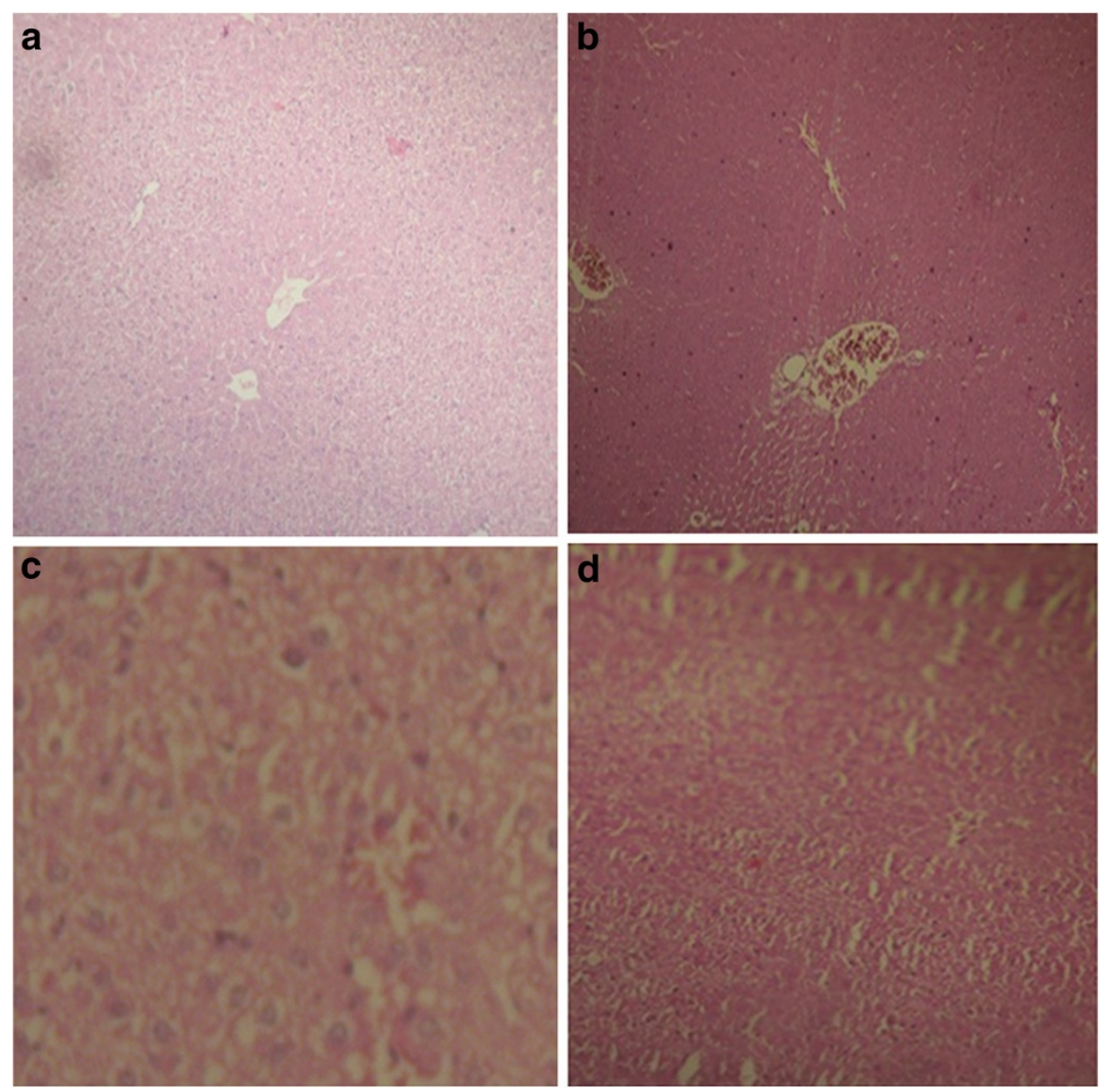

Figure 4 Effect of $L$ on liver of mice (a) control (b) high-fat-diet (c) $L$ treated group $(900 \mathrm{mg} / \mathrm{kg})(\mathrm{d}) \mathrm{L}$ treated group $(400 \mathrm{mg} / \mathrm{kg})$. 
insulin-dependent diabetes mellitus etc. A number of herbal extracts have been reported for their anti-obesity activities and are being used in Ayurveda for the same. Stellaria media is commonly used as salad herb for control of obesity but has not gained much importance as medicine due to lack of sustained scientific evidence. In the present study the effect of LJ of Stellaria media on digestive enzymes was assessed. $\alpha$-amylase, one of the digestive enzyme secreted from the pancreas and salivary glands, is involved in an important biological process such as digestion of carbohydrates. Many crude drugs inhibit $\alpha$-amylase activity [23]. Natural $\alpha$-amylase inhibitors have been demonstrated to be beneficial in reducing post-prandial hyperglycemia by slowing down the digestion of carbohydrates and, consequently the absorption of glucose. Reducing post-prandial hyperglycemia prevent glucose uptake into adipose tissue to inhibit synthesis and accumulation of triacylglycerol [24]. On the other hand, it is well known that dietary lipid is not directly absorbed from the intestine unless it has been subjected to the action of pancreatic lipase. The two main products formed by the hydrolysis of pancreatic lipase are fatty acid and 2-monoacylglycerol. Based on these facts, inhibition of these digestive enzymes is beneficial in treatment of obesity. In in vitro studies LJ has exerted dose dependent inhibitory activity on $\alpha$-amylase and pancreatic lipase. The inhibition of lipase by $\mathrm{LJ}\left(\mathrm{IC}_{50}\right.$ value; $3.71 \mathrm{mg} / \mathrm{ml}$ ) was stronger than that of $\alpha$-amylase ( $\mathrm{IC}_{50}$ value; $4.53 \mathrm{mg} / \mathrm{ml}$ ). the LJ has significantly decreased post-prandial triglyceride level at 3 and $4 \mathrm{~h}$ in in vivo studies at the dose of $900 \mathrm{mg} / \mathrm{kg}$ body weight. The study was continued to evaluate the effect of LJ on obesity in mice fed a high-fatdiet for six weeks. The administration of LJ at $900 \mathrm{mg} / \mathrm{kg}$ significantly suppressed the body weight of the mice. The inhibition of gain in body weight did not depend upon the decreased food or energy intake as there was no significant decrease in diet intake between the positive control and test groups, but was caused by preventing/delaying of fat and carbohydrate absorption. Long term feeding of LJ at the dose of $900 \mathrm{mg} / \mathrm{kg}$ to mice caused significant changes in blood parameters viz; decreased levels of total cholesterol, total triglyceride, and LDL- cholesterol, but an increased HDL-cholesterol level.

It has been demonstrated that tea saponin [25], saponin in Platycodi Radix [26,27] all belonging to the family of oleanene-type triterpenoid saponin; phenolic compounds [28] and flavonoids [29] showed strong inhibitory effects on pancreatic lipase and suppressed the increase of body weight induced by a high-fat-diet. Stellaria media is reported to possess oleanene-type triterpenoid saponin [9]. Our study quantified the presence of oleanene-type triterpenoid saponin, phenols and flavonoids in LJ which seems to be responsible for preventing high-fat-diet induced obesity.

\section{Conclusion}

In conclusion, Stellaria media may prevent high-fat-diet induced fat storage in adipose tissue by inhibiting the intestinal absorption of dietary fat and carbohydrates through inhibition of digestive enzymes.

\section{Competing interests \\ The authors declare that they have no competing interests.}

\section{Authors' contributions}

NR designed and planned the study; carried out experimental work, biochemical analysis, statistical analysis, interpretation and discussion of results related to their part of the work. SKS and NV designed and planned the study; drafted and revised the manuscript. NV checked and corrected the English language. All authors read and approved the final manuscript.

\section{Acknowledgement}

The authors are highly grateful to the Institutional Animal Ethics Committee (IAEC) for providing me the laboratory animals for the research project (IAEC Registration number 0436)

Received: 6 February 2012 Accepted: 24 August 2012

Published: 3 September 2012

\section{References}

1. Mokdad AH, Ford ES, Bowman BA, Dietz WH, Vinicor F, Bales VS, Marks JS: Prevalence of obesity, diabetes, and obesity-related health risk factors. J Am Med Assoc 2003, 289:76-79.

2. Aronne LJ: Modern medical management of obesity: the role of pharmaceuticaintervention. J Am Diet Assoc 1998, 98:S23-S26.

3. Hartz AJ, Rupley DC Jr, Kalkhoff RD, Rimm AA: Relationship of obesity to diabetes: influence of obesity level and body fat distribution. Prev Med 1983, 12:351-357.

4. Morikawa T, Muraoka O, Yoshikawa M: Pharmaceutical food science; search for anti-obese constituents from the flowers of Bellis perennis. Yakugaku Zasshi 2010, 130(5):673-678.

5. Birari RB, Bhutani KK: Pancreatic lipase inhibitors from natural source: unexplored potential. Drug Discov Today 2007, 12:879-889.

6. Sharma R: Medicinal Plants of India: an Encyclopaedia. Delhi: Daya Publishing House; 2003:234.

7. Pande A, Shukla YN, Tripathi AK: Lipids constituents from Stellaria media. Phytochemistry 1995, 39:709-711.

8. Vanhaecke M, Ende WVD, Lescrinier E, Dyubankova N: Isolation and characterization of a pentasaccharide from Stellaria media. J Nat Prod 2008, 71:1833-1836.

9. Hu YM, Wang H, Ye WC, Qian L: New triterpenoid from Stellaria media (L.) Cyr. Nat Prod Res 2009, 23(14):1274-1278.

10. Duke JA, Godwin MJB, Duke PAK: Handbook of Medicinal Herbs. New York: CRC Press; 2002:183.

11. Howard M: Traditional folk remedies: a comprehensive herbal. London: Century Publications; 1987:119.

12. Indian Pharmacopoeia: Government of India, Ministry of Health and Welfare. New Delhi: Controller of Publications; 1996:A 53-A 54.

13. WHO: Quality Control Methods for Medicinal Plants. Geneva: World Health Organisation; 2005

14. Harbone JP: Phytochemical methods, a quide to modern technique of plant analysis. London: Chapmann and hall; 1973:1-271.

15. Singleton VL, Rossi JA Jr: Colorimetry of total phenolics with phosphomolybdic- phosphotungstic acid reagents. Am J Enol Vitic 1965, 16:144-153.

16. Lamaison $J \mathrm{~L}$, Carnet A: Teneurs en principaux flavonoides des fleurs de Cratageus monogyna Jacq et de Cratageus Laevigata (Poiret D.C) en Fonction de la vegetation. Plantes Medicinales Phytotherapie 1991, XXV:12-16.

17. Hurst WJ, Mckim JM, Martin RA: High-performance liquid chromatographic determination of glycyrrhizin in licorice products. J Agric Food Chem 1983, 31:387-389.

18. Xiao Z, Storms R, Tsang A: A quantitative starch-iodine method for measuring alpha-amylase and glucoamylase activities. Anal Biochem 2006, 351:146-148. 
19. Yoshikawa M, Nishida N, Shimoda H, Takada M, Kawahara Y, Matsuda H: Polyphenolconstituents from Salacia species: quantitative analysis of mangiferin with alpha-glucosidase and aldose reductase inhibitory activities. Yakugaku Zasshi 2001, 121:371-378.

20. Han LK, Kimura Y, Okuda H: Reduction in fat storage during chitinchitosan treatment in mice fed a high-fat diet. Int J Obes 1999 , 23:174-179.

21. Lee H, Kang R, Yoon Y: SH21B, an anti-obesity herbal composition, inhibits fat accumulation in 3 T3-L1 adipocytes and high fat dietinduced obese mice through the modulation of the adipogenesis pathway. J Ethnopharmacol 2010, 127:709-717.

22. Carleton H: Histological Techniques. 4th edition. London: Oxford University Press; 1979.

23. Kobayashi K, Satio Y, Nakazawa I, Yoshizaki F: Screening of crude drugs for influence on amylase activity and postprandial blood glucose in mouse plasma. Biol Pharm Bull 2000, 23:1250-1253.

24. Maury J, Issad T, Perdereau D, Gouhot B, Ferre P, Girard J: Effect of acarbose on glucose homeostasis, lipogenesis and lipogenic enzyme gene expression in adipose tissue of weaned rats. Diabetologia 1993, 36:503-509.

25. Han LK, Kimura Y, Kawashima M, Taniyama T, Hayashi T, Zheng YN, Okuda H: Anti-obesity effects in rodents of dietary tea saponin, a lipase inhibitor. Int $J$ Obes 2001, 25:1459-1464.

26. Han LK, Xu BJ, Kimura Y, Zheng YN, Okuda H: Platycodi radix affects lipid metabolism in mice with high fat diet-induced obesity. J Nutr 2000, 130:2760-2764.

27. Han LK, Zheng YN, Xu BJ, Okuda H, Kimura Y: Saponins from Platycodi radix ameliorate high fat diet induced obesity in mice. J Nutr 2002, 132:2241-2245.

28. Nakai M, Fukui Y, Asami S, Ono YT, Iwashita T, Shibata H, Mitsunaga T, Hashimoto F, Kiso Y: Inhibitory effect of Oolong tea polyphenols on pancreatic lipase in vitro. J Agric Food Chem 2005, 53:4593-4598.

29. Kamisoyama H, Honda K, Tominaga Y, Yokota S, Hasegawa S: Investigation of the anti-obesity action of licorice flavonoid oil in diet-induced obese rats. Biosci Biotechnol Biochem 2008, 72(12):3225-3231.

doi:10.1186/1472-6882-12-145

Cite this article as: Rani et al:: Quality assessment and anti-obesity activity of Stellaria media (Linn.) Vill. BMC Complementary and Alternative Medicine 2012 12:145.

\section{Submit your next manuscript to BioMed Central and take full advantage of:}

- Convenient online submission

- Thorough peer review

- No space constraints or color figure charges

- Immediate publication on acceptance

- Inclusion in PubMed, CAS, Scopus and Google Scholar

- Research which is freely available for redistribution 